\title{
Codes of Conduct and Framework Agreements on Social Minimum Standards-Private Regulation?
}

\author{
EVA KOCHER
}

\section{INTRODUCTION}

C

orporate Social Responsibility (CSR) is currently a widely discussed topic (Sheikh, 2002: 143-50; Riedel et al, 2003; HauserDitz and Wilke, 2005; KPMG, 2005; Riess and Peters, 2005). ${ }^{1}$ Many corporations and employer associations have tackled the subject and committed themselves to CSR policies. In addition, since the creation of the 'Global Compact' (Körting, 2006) there has been increased knowledge of what CSR comprises.

Many German companies (that is, those with German headquarters) claim to have always practised corporate social responsibility. However, doubts remain as to how CSR can be used in the specific context of German industrial relations that rely on collective bargaining between employee representation at the shop-floor level (Works Councils) as well as at the branch level (trade unions).

The European research project ESTER is an empirical study undertaken to determine whether the concepts included in CSR will serve to strengthen and export the 'European social model' or instead threaten it $^{2}$ (for the European social model see: Kaelble, 2000; Lavranu, 2000; Blanke and Hoffmann, 2006). In the summer of 2005, research teams in seven European countries each conducted about 40 interviews with representatives from different corporations, trade unions, employee representatives at the shop-floor level, advocatory NGOs, consumer organisations, business associations, etc. The study by no means intends to be representative, but rather hopes to glean deeper insights into the

\footnotetext{
1 COM (2001: 366) Commission of the European Communities, Green Paper 'Promoting a European framework for Corporate Social Responsibility'.

2 ESTER, Régulation Sociale des Entreprises Transnationales Européennes.
} 
possible motives of and approaches taken by different actors from these anonymous interviews.

First results point towards possible conflicts between CSR concepts and traditional German labour relations (Hoffmann, 2004). Corporations are reluctant to use CSR concepts. On the one hand, there is a feeling that they have always practised corporate social responsibility by simply adhering to German labour laws or by complying with the ethics of their specific corporate identities or business (for example, family business or cooperative culture). On the other hand, there is the feeling among various actors that CSR may in fact mean something different from conventional German industrial practices. This is a main reason why many German trade union representatives are wary of CSR. As one interviewee puts it: 'So what made us a bit suspicious was that the employer associations demand the dismantling of codetermination, on the one hand; not complete dismantling, that is, but a reduction in the level of codetermination. And, on the other hand, they are promoting CSR at the same time.' 3

In the cases studied, CSR policies have not been limited to internal organisational projects, sponsorship, or 'corporate citizenship' projects, but also relate to core business activities, by regulating the repercussions arising from production and distribution, such as employment conditions (cp Bassen et al, 2005; KPMG, 2005: 6). The voluntary and non-binding character of those CSR policies will be examined in this chapter, first by analysing the regulatory intentions and legal nature exhibited by corporate codes of conduct (section II). Section III explores hard law rules able to bind enterprises to their own rules once these have been adopted. Lastly, section IV asks whether corporate codes of conduct do not just affirm rules that enterprises would have to abide by in any event.

\section{THE LEGAL NATURE OF CODES OF CONDUCTS: VOLUNTARY AND NON-BINDING?}

\section{A. Social Standards in Instruments of Self-Regulation}

Unilateral corporate declarations of commitment are used as instruments of CSR policies. In 'codes of conduct', 'standards of engagement', and 'social charters', transnational enterprises publicly declare that they will adhere to certain minimum social standards in transnational production (that is, production in establishments operating outside Europe or in a transnational supply chain). In addition, and especially in Europe, there have been more and more contracts between transnational enterprises and social actors (namely international trade unions, but also sometimes European Works

\footnotetext{
3 All quotes translated from the original German interviews.
} 
Councils or World Works Councils)—so-called International Framework Agreements (IFAs). For example, Volkswagen's 'Declaration on social rights and industrial relations' was signed by the board of management, the World Works Council, and the International Metalworkers' Federation (Hammer, 2005; Hepple, 2005: 69-80; Greven, 2006: 10-15; Weinz, 2006). ${ }^{4}$ The term 'code of conduct' will be used here as a general term, and will include within it International Framework Agreements.

In most of these instruments, companies commit themselves to apply the standards not only within the respective company, plants, and establishments inside and outside Europe, but also in the group of companies (that is, in dependent companies). Often, but not always, companies pledge to make sure that their business partners (contractors, subcontractors, suppliers) also meet certain standards (Wilhelm and Mauritz, 2005: 20-21). Sometimes, social standards are included as a supplier's obligation in corresponding commercial contracts with supplier companies in developing countries. In fact, many companies with complex supply chains, particularly in the textile and retail sectors, use this approach as a means to gain control over the supply chain and legally enhance supply chain management. Incorporating codes of conduct into these contracts is usually achieved by buyers imposing certain standard contract terms (van Liemt, 2000: 177; Fichter and Sydow, 2002: 357-80; Kocher, 2002: 265-80; Kocher, 2004a: 27-31). Furthermore, nowadays many European companies themselves must promise to observe certain social standards throughout the transnational supply chain in their contracts with commercial and other partners. This is true, for example, of suppliers in the automotive industry. In the retail and textile industries, certain actors such as political sports associations, in their capacity as sponsors and licensees, tend to demand that producers comply with social standards in the production of sportswear. ${ }^{5}$

\section{B. Contents of Corporate Codes of Conduct and Framework Agreements}

What is the common understanding of 'social standards' found in these codes? While transnational US or Dutch companies have been using codes of conduct since the beginning of the 1990s to institute transnational social standards, the current German understanding of CSR developed only in the late 1990s or early 2000 (KPMG, 2005: 4-6). The main reasons for this new

\footnotetext{
${ }^{4}$ Declaration of 6 June 2002, in Arbeit und Recht 2002 at 343; in addition, an 'Agreement on industrial health and safety policy' was signed by the same parties on 29 September 2004.

5 See, eg Agreement of FIFA with the international trade union IC-FTU, September 1996.
} 
corporate approach seem to be globalisation and the assumption of a global player's corporate identity. The revision of the OECD guidelines in 2000 may have also contributed to this development, but the ILO Declaration on core labour rights of $1998^{6}$ (Alston, 2004; Langille, 2005: 409-37), and the establishment of the Global Compact in 1999/2000 seem to have been the decisive external turning points leading to these new approaches. This is due to the fact that normative orientations in Germany seem to have focused on the ILO core labour standards (to which the Global Compact and the new OECD guidelines also refer) (Tapiola, 2000: 9-16; Ölz, 2002: 330; Kocher, 2004a: 27-31).

As a consequence, German codes of conduct or social charters usually cover the abolition of child and forced labour, ${ }^{7}$ non-discrimination, ${ }^{8}$ and a guarantee of freedom of association and collective bargaining ${ }^{9}$ (Dubin, 1999: 47-9; Engels, 2000: 219-31). Minimum standards on working time, wages, and other working conditions are also often included, although such guarantees are not always very specific. Framework agreements and some unilateral codes also mention standards on qualification of the workforce. Furthermore, there is always an assurance that standards set out under national law will be met (Herberg, 2002: 45).

Overall, the ILO core labour standards nowadays seem to constitute the lowest common denominator for German corporations when it comes to regulating social standards in private instruments (Kocher, 2004a: 27). ${ }^{10}$ When asked about normative approaches, however, corporate representatives mention various sources for guidance. Most actors refer to the ILO core labour standards, the OECD guidelines, and the Global Compact. One actor mentioned 'the global eight', namely, the Global Compact, the ILO core labour standards, the OECD guidelines for multinational enterprises, ISO 14001, Accountability 1000, the Global Reporting Initiative (GRI), the Global Sullivan Principles, and Social Accountability 8000 (SA 8000). Other actors make reference to the Global Compact (which itself refers to the ILO core labour standards), the Charter for sustainable development of the International Chamber of Commerce, the OECD guidelines (revised, in 2000, in accordance with the ILO core labour standards), certification of production locations in accordance with the standards EMAS and ISO 14001, as well as the GRI guidelines.

\footnotetext{
${ }^{6}$ For the 1998 ILO Declaration on core labour standards, see also IV.B below.

7 ILO Convention No 29 (on forced labour, 1930), No 105 (on the abolition of forced labour, 1957), No 138 (on minimum age, 1973), and No 182 (on the prohibition of the worst forms of child labour, 1999).

${ }^{8}$ ILO Convention No 100 (on equal pay, 1951), and No 111 (on non-discrimination at work, 1958).

9 ILO Convention No 87 (on freedom of association, 1948) and No 98 (on collective bargaining, 1949).

${ }^{10}$ However, the ILO core labour standards are not always explicitly referred to.
} 


\section{Regulatory Character of Codes of Conduct and International Framework Agreements}

\section{General Ideas}

Since codes of conduct are embedded in norms of both hard law (ILO Conventions, national law) and soft law (OECD Guidelines, ILO Declaration on core labour standards), one should be sceptical of the regulatory character attributed to them. Are these undertakings really meant to establish original 'regulation' of working conditions in subsidiaries or in the supply chain in Third World countries? Can they be considered as 'soft law'?

The term 'soft law' in its widest sense (Hailbronner, 1982: 113; Ballreich, 1989: 383; Ehricke, 1989: 1907) captures all kinds of standards, social rules, and business practices that create trust and, thus, give rise to the emergence of legitimate expectations, have relevance in formal/hard law, and can serve as catalysts in a process which may (in the future and via hard law bridges) lead to a binding legal norm (Teubner, 1971: 45; Scherrer et al, 1998: 12; Winter, 2005: 24-30).

'Private regulation' could be categorised as 'paralegal' or 'soft law', on the basis that corporate actors themselves seem to deliberately create legitimate expectations by referring to codes of conduct as setting out normative and regulative standards (Herberg, 2005: 110). However, on closer look at the undertakings we studied, we find, in fact, that they leave room for doubt as to their 'legal' or 'para-legal' character; it is not always clear if the corporate actors actually intend to create legitimate expectation through these specific instruments (see Simma and Zöckler, 1996: 80 whose work provides the basis for the approach taken in this section). First, it is doubtful that the adoption of codes of conduct results in the creation of new standards per se. This is because, as previously noted, corporate standards draw heavily on international regulation at ILO level or standards defined elsewhere. Second, it is clear that corporations mostly do not intend to create rights for their employees or those of their suppliers. As explicitly stated in the VW-Social Charter, ${ }^{11}$ which is consistent with every other framework agreement signed by a trade union: 'No claims whatsoever by third parties may be asserted under this declaration.' Furthermore, corporations often imply, or sometimes even explicitly declare that the code of conduct is merely a restatement of what has always been corporate practice and policy, and that it only serves to 'document' the promotion of social rights and fundamental principles: this casts further doubt on the regulatory nature of such codes. Third, the lack of specifics in many unilateral declarations (Herberg, 2005: 83) and framework agreements points to an insufficiency of proper

11 See $\mathrm{n} 3$ above. 
constitutive regulatory intent. For example, in the case of child labour, only a few of these codes set clear limits on the age of employees or their working hours. In fact, most codes provide only a general outline regarding the applicable labour standards, and ultimately refer to national law (for example, 'abolition of exploitative child labour ... and ... observance of the minimum age to be attained for the authorisation to take up employment in accordance with the respective national regulations' ${ }^{12}$ ). On the other hand, in three out of our four case studies, the wording of such codes usually goes beyond simply describing policy objectives. These private standards seem to constitute more than mere policy objectives which would have no legal or para-legal value and would not have the capacity to create legitimate expectations. Overall, it seems that corporate standards can most adequately be described as 'declaratory' and 'promotional', by setting out a normative framework or key corporate practices together with relevant implementation mechanisms.

\section{Relationship to Other Hard Law and Soft Law Standards}

It could be argued that there is no need for the codes to establish specific standards, since they implicitly refer to norms laid out in other instruments (especially in the ILO Conventions). However, although the codes often refer to various normative standards, these standards are by no means congruent with each other. For example, SA 8000 lays out a standard regarding workers' wages based on ensuring a livelihood ('living wage'); this differs from the Fair Labour Association's (FLA) code of conduct, which requires only that 'national minimum wages' be paid. All the companies studied used the standard requiring a 'legally prescribed minimum wage, or a wage customary in the trade if this exceeds the minimum wage' or some other formula. Moreover, none of the companies examined included the living wage' standard in their corporate codes, although two corporate representatives did mention that the SA 8000 approach was taken as a starting point: 'We have the SA 8000 , of course, which we also took as a basis. But we found that it's too divorced from reality. It's very demanding, and that's a target to aim for, that you don't pay according to minimum wages.' A statement by a representative of a European Works Council (EWC) sheds further light on this issue:

In the way we actually understand CSR, we ... always oriented ourselves, but never absolutely referred to, let's say, 100 per cent or 105 per cent RAI or SA 8000 or whatever, but actually always said, okay, we have to see for ourselves what our resources, what our requirements are, that are hardly comparable in South Africa or China or places like that ...--develop a lot in Germany, okay,

12 Deutsche Telekom AG, Social Charter of 2003. 
but then, so to speak, implement it differently, according to the cultural situation as it is and the level of development, absolutely according to legal requirements in the respective countries.

Two corporate representatives explicitly stated that their codes of conduct were developed at their head office, and then adapted to meet local requirements placed on their regional offices. One of them said:

Otherwise we're also very keen to apply aspects of our standards that are as specific as possible locally, and that's why we always resisted accepting standard clauses that, in our view, are totally unrealistic; we can put together any number of standards and codes, but what matters at the end of the day is how we can set up a process to work towards these standards and also gradually achieve comprehensive improvements. And a $110 \%$ standard is no help to us there; it's a question of reaching a standard in which the management of a supplying firm can find its views reflected.

\section{Relationship to National Law and Local Practice}

These citations confirm the suspicion that if one wishes to examine the regulatory character of these codes, the common references to 'national regulation', 'national law', or 'local practice' could give us more information on the regulatory intent and concept. The wording of the codes does not always give clear answers to the question whether the company standard will take precedence over local law or practice at the place of production, or if the interpretation of national law will rather determine the interpretation of the standards. The difficulty of reconciling possible contradictions between self-imposed obligations and national laws was mentioned in several interviews. One company representative cited Thailand as an example: here, the code of conduct called for a maximum 48-hour working week; where overtime was worked, the maximum increased to 60 hours. According to one interviewee, since the law in Thailand allowed for far more than 48 hours a week to be worked, suppliers there said 'quite rightly, of course' that employees could be found working more than 60 hours a week. Thus, the corporate representative in the German office was of the view that one could only gradually move towards the 60-hour limit. This decision seems to reflect an approach that favours applying the lowest standard required under national law.

Another problem regarding the application of social norms in transnational production might be termed the 'cultural objection'. As stated by one corporate representative on the question of the transfer of social standards: 'first, we don't want it, and, second, we can't do it anyway: to take abroad or transfer as an export hit, just like that, certain cultural things that have developed naturally in Germany.' It should be noted that this objection to a transfer of social standards arises in regard to standards that have been 
established in the company's 'voluntary' code of conduct and that are more or less congruent with standards set out by the ILO, that is global standards created for universal application. Another representative of a company that also publicly declared its adherence to universal ILO standards, including non-discrimination, stated:

$[\mathrm{O}] \mathrm{n}$ culture-we always go at it with our German way of thinking... . A Pakistani will either hire only men or only women. He'll never mix them because he's a Muslim. Like hell he will. So either he employs only men or only women ... and there we have classic discrimination. How are we going to deal with it? If he employs men and women together, he has a much bigger problem.

It is clear from this statement that the corporate representative does not intend to enforce or at least affirm the standard of non-discrimination against a cultural objection. Cultural relativism constitutes a fundamental problem for the implementation and enforcement of universal standards. However, none of the enterprises that uses a cultural excuse thinks of abandoning or adapting the standard of non-discrimination or some other standard.

It is also possible that the opposite situations can occur, such that a standard set out in national law is more protective than that set out in the code of conduct. In at least one of the cases we studied, the position taken on child labour in the corporate code of conduct was changed to reflect amendments to the national laws of the 'principal countries' of production, and the working age was raised from 14 to 15 years. As observed by one NGO representative:

The NGOs in Central America, for example, say that the labour law that exists is much more important for them; that's national legislation, and a company is required to stick to it here. That means they actually have very little use for the code of conduct tool. And why should they? The labour law is good. They should simply stick to it.

In such cases, when NGOs campaign for the observance of national labour law, companies accordingly tend to concern themselves with national rules and thus seem to accept the prevalence of national law as a normative orientation to be respected. Issues of national law thus enter corporate CSR policies by way of 'agenda setting' by NGO campaigning; we were told, for example, of one case where the day of menstruation leave to be granted under Indonesian law was enforced this way.

Interesting in this respect is the handling of China, a country where implementation of social standards in production is generally viewed as problematic. In view of the general lack of industrial health and safety standards, but also certain deficiencies regarding freedom of association, representatives of companies with business activities or cooperations in China have made it clear that transnational enterprises do not regard themselves 
as firms that stand in opposition to the government. It was observed by some representatives that various organisations had failed in their attempts to gain greater influence in China, because they had confronted the government with expectations that the state could not ultimately meet. In view of the 'huge enforcement deficit' in China, one commentator was quoted as saying:

[W] assume that, of course, the Chinese government also has an interest in seeing that the laws there are in the country on this issue are gradually implemented ... And now the question arises as to how, by supporting the Chinese government, international companies can perform support, a supporting role.

Thus, where there are conflicts between 'local custom' and company standards such as codes of conduct (which contain 'guarantees' of freedom of association, collective bargaining, and non-discrimination), local practice, even where it is found to be insufficient, will be likely to have primacy. For example, when asked about the implementation of the guarantee of freedom of association in China, one company representative stated:

We say there needn't be a union at the location, and if having a union is prohibited by law, then that does not meet our standard. It becomes difficult the moment the employees come and say, we want a union. Luckily, there isn't anything like that right now, thank goodness.

Obviously, this company is relieved not to have been forced to take a stand on the question of freedom of association, and, faced with an unsatisfactory local practice of non-compliance, has not acted. The same speaker said:

$[T]$ he important thing for us ... is that we also demand, by means of a standard, that employees in one way or another get the opportunity to represent their interests vis-à-vis company management. And, partly, these can be very simple things; it can be I have complaints management, I have a box and I can stick a letter in it, or I'm the responsible person from among my ranks who can then, let's say, can appear in front of management.

An internal complaints mechanism in corporate ownership is here identified with the promotion of freedom of association.

This example shows a relevant actor who does not expect the written document to actually function as constitutive standard-setting on its own. New standards will only be firmly established and specified as implementation policies are put in place, and subsequently monitored.

\section{Providing Enforcement Mechanisms for Existing Standards}

Corporate actors have cited the lack of adequate enforcement mechanisms as a key reason why, although ratified, the standards set out in the ILO 
and human rights agreements have not been observed in many states where suppliers or subsidiaries have business operations. In their view, codes of conduct function to give teeth to such existing standards by providing for enforcement mechanisms. Many declarations and contracts contain provisions that define how to monitor and implement compliance.

Control and monitoring procedures are diverse and varied, but they all have one common aspect: control and monitoring does not rely on legal and judicial mechanisms, but on mechanisms owned by the transnational standard-setters themselves. Only in rare cases, such as where the transnational corporation is facing political risks and/or market pressure, are independent or external actors and organisations chosen as auditors (Dubin, 1999: 62; Colucci, 2000: 277-89; van Liemt, 2000: 185).

As a consequence, what has been observed is more than just promotional standard-setting, which provides standards developed elsewhere with implementation and control mechanisms. Rather, specific standards emerge as a result of the implementation and monitoring processes. This could be referred to as the 'reflexivity' of standards (for the concept of reflexivity see: Teubner, 1984: 334; Teubner and Willke, 1984: 4; Habermas, 1997: 495; Calliess, 2000: 293). In the future, the involvement of legitimate actors in the implementation of standards as well as participative approaches to implementation and monitoring (especially trade union participation and, consequently, freedom of association/right to collective bargaining) will have to be discussed further.

\section{CODES OF CONDUCT BETWEEN SOFT LAW AND HARD LAW}

In view of these results, doubts arise as to the effective regulatory character of existing corporate codes of conduct. However, up to this point, only the performative value and normative quality of the texts, documents, and social practices of private standard-setting have been examined. Nevertheless, soft law standards such as unilateral declarations on minimum standards can be transformed into legal regulation and binding obligations through hard law norms. In the following section, the respective normative reference points and legal prerequisites for recognising a binding legal nature of standards will be examined (Kocher, 2002: 265-80; Dilling, 2005: 283-313; Glinski, 2005: 187-230; Kocher, 2005: 647-52).

\section{A. Misleading Advertising}

One key issue concerns cases where a company promotes its products on the basis that they were produced in compliance with certain minimum social standards, and specifically whether such a company could be found in violation of section 5(1)-(2) UWG (German Act against Unfair 
Competition) prohibiting misleading or unfair advertising (Kocher, 2005: 647). It is clear that an advertisement will be found misleading if the company does not meet in practice what it claims to fulfil in the advertising. Moreover, the courts have demanded that the advertisement of an image, which is connected to certain socially desirable aims, be accompanied by a certain degree of information on what 'socially responsible' is actually supposed to mean (Ewert, 1997; Glinski, 2005: 210) ${ }^{13}$. This finding is more or less consistent with the provisions of the new Directive 2005/29/EC concerning unfair business-to-consumer commercial practices, which requires in Article 6(2):

A commercial practice shall also be regarded as misleading if, in its factual context, taking account of all its features and circumstances, it causes or is likely to cause the average consumer to take a transactional decision that he would not have taken otherwise, and it involves any marketing of a product, including comparative advertising, which creates confusion with any products, trade marks, trade names or other distinguishing marks of a competitor.

The new regime now explicitly includes situations where a trader has failed to comply with certain commitments, which are not simply aspirational but are rather firm and capable of being verified, that he has undertaken as binding and where he has indicated through his commercial practice that he intends to be bound by the code (Glinski, 2005: 212). The commitments set out in many codes are likely not to meet the criteria of 'firm' and 'capable of being verified'; however, any determination depends on the specific wording of the code itself.

Where a commitment is found to be neither firm nor verifiable, one should consider whether it is a misleading practice for a company to suggest to consumers that it has made a firm commitment, despite the fact it has not. There are few cases where the social practices of transnational corporations have been questioned by means of the rules on unfair competition. The vast majority of these cases arose in the United States, where public interest actions are considered to have some legitimacy and where there is an institutionalised system and network for public interest legal advocacy (Pfarr and Kocher, 1998: 135; Kocher, 2004b: 216). For example, in the United States, NGOs have brought actions against the retail industry; the Saipan-case in particular garnered a huge amount of public attention. In this case, a whole group of retailers was accused of misleading advertising under the California Business and Professions Code, because they sold Saipan products in California as 'made in USA', suggesting that nonsweatshop production methods were used. In the consent decree that concluded the class action suit, 26 retailers and 23 production companies

13 BGH, 5.12.1996 in Der Betrieb 1997 at 2119-20, BGH 20.10.1988 in GRUR 1991 at 548-50. 
paid a lump sum of USD 20 million (Kocher, 2004b: 209-23; Su-Ping, 1999/2000: 601-29; Glinski, 2005: 205). In this NGO attempt to control social practices in transnational production, the US rules on misleading advertising (functionally equivalent to the German regime) seem to have worked as an adequate instrument.

\section{B. Consumer Contract Law}

Regarding issues of consumer contract law, it is worth taking a closer look at the European Directive 1999/44 on certain aspects of the sale of consumer goods, ${ }^{14}$ which states in Article $2(2 \mathrm{~d})$ that

consumer goods are presumed to be in conformity with the contract if they show the quality and performance which are normal in goods of the same type and which the consumer can reasonably expect, given the nature of the goods and taking into account any public statements on the specific characteristics of the goods made about them by the seller, the producer or his representative, particularly in advertising or on labelling.

After transposition of the Directive, section 434 (1) BGB (German Civil Code) has been reworded accordingly (Rott and Glinski, 2003: 649-54; Glinski, 2005: 220). The German law on the sale of goods has already established that public declarations made for promotional purposes may have contractual value and, thus, create contractual obligations to consumers. ${ }^{15}$ However, it is questionable whether a publicly advertised code of conduct which guarantees that certain minimum social standards were maintained during production will meet the requirement that such declarations be 'specific characteristics of the good' under the German provision. In the past, the German judiciary has been reluctant to recognise characteristics other than those physically attached to the purchase as 'characteristics of the good'. ' $[\mathrm{O}]$ ther economical, social or legal attributes of the good ... that influence its usefulness or value may be considered. But such attributes must be based on the quality of the good and be attached to it for some time'. ${ }^{16}$

It is arguable that it is not simply a question of 'business ethics' where a company has advertised that it is in compliance with certain minimum social standards in the production of its goods. If the market recognises this aspect of the product, then the mode of production would have to be considered a feature of the good itself (Dilling, 2005: 288; Glinski, 2005: 223). On this basis, the code of conduct would then become a contractual obligation to be performed by companies for the benefit of consumers. Nevertheless, the strength of this obligation would still be dependent upon the specific wording

14 OJ L 171, 07/07/1999 at 12-16.

$15 \mathrm{BGH}, 21.6 .1967, \mathrm{BGHZ} 48$ at 118.

$16 \mathrm{BGH}, 28.3 .1990, \mathrm{BGHZ} 111$ at 75 (trans). 
and content of the code in question, and, as has been shown in this chapter, such commitments vary widely in respect of their regulatory character.

\section{CODES OF CONDUCT AS A CONTRIBUTION TO TRANSNATIONAL LAW}

Another question is whether the corporate undertakings guaranteeing certain social minimum standards are really 'voluntary' in the sense that a company can freely decide to commit to these minimum standards. Are they not anyway bound to the same minimum standards that they 'voluntarily' commit themselves to? Since corporations publicly commit to consumers that they will meet certain social aims, both consumer law and the law on unfair competition will likely come to bear on this issue.

\section{A. Social Dumping and the Law against Unfair Competition}

Under German law, it is commonly (if questionably) assumed that an act which merely takes advantage of an international gradient in the level of protection without violating any legal norms cannot be considered unfair competition. 'Social dumping' as such will thus not be considered to be contrary to principles of fair competition.

Under sections 3 and 4, no 11 UWG (German Act against Unfair Competition) a commercial practice will be unfair if a competitor violates a legal provision that serves, inter alia, to regulate commercial behaviour in the interest of commercial actors. There have been few decisions on the question of whether the failure to meet certain minimum social standards aimed at protecting workers constitutes unfair trading for the purposes of this rule or under the new codification of these rules under section 4, no 11 UWG. However, the German Federal Civil Court (BGH) has found that an entrepreneurial action restricting itself to the production process will usually not be regarded as commercial trading activity. Thus, infringements of labour law standards constitute unfair competition only if the violation occurs where the commercial activity involves the sale of the product. Thus, violations of working time rules will not be considered unfair competition, but a violation of the rules on closing time for shops or a prohibition for bakeries to bake at night could be found to be unfair trading. ${ }^{17}$ The Federal Civil Court held that a contravention of the minimum standards on wages

$17 \mathrm{BGH}$ in GRUR 1989 at 116 (prohibition on baking bread at night); BGH, 7.6.1996 in GRUR 1996 at 786 (selling of flowers at petrol stations); BGH, 19.5.1982 in BGHZ 84 at 130 (marketing in airports after shop closing hours as unfair competition); BGH, 8.12.1983 in NJW 1984 at 872 ('information for housewives' after shop closing hours as unfair competition); BGH, 26.11.1987 in NJW 1988 at $2243 \mathrm{ff}$ (distribution of a advertising journal on Sundays as unfair competition). 
or health and safety will be seen as a commercial activity if the violation is broad and systematic, and if the profits resulting from the violation are deliberately used to calculate a more favourable price for the goods. ${ }^{18}$

The principles on unfair competition set out by the German Federal Civil Court can be applied to cases where there has been a violation of certain minimum standards under international and foreign law, if the violated norms are found to be 'legal provisions' in the sense of section 4, no 11 UWG. For these purposes, the laws of the country of production are definitely to be considered 'legal provisions'. However, the ILO Conventions do not directly bind private enterprises. In the case of an infringement of ILO standards, the rules of section 4, no 11 UWG do not apply in the same way. In 1980, the German Federal Civil Court (BGH) had to decide a case where a producer of asbestos had purchased a considerable proportion of his products in South Korea, where the health and safety standards for workers were lower than in Germany. As a result, it was possible for this producer to undercut his competitors' prices. Since the asbestos production did not violate South-Korean law, the court did not see any unfair competition in the distribution of the goods. The fact that the conditions of production violated the ILO Convention on Asbestos (No 139 of 24 June 1974) was not seen as relevant (Knieper and Fromm, 1980: 2020; Oppenhoff, 1980: 862), ${ }^{19}$ and the reform of the German law on unfair competition in 2004 has not changed anything in this respect. Nevertheless, it is important to note that, in the case of the asbestos products, the Convention on Asbestos had only been signed by 15 of the more than 100 Member States of the ILO. This factual detail was important in the case: the Federal Civil Court did consider that, under certain conditions, this might have been a case of unfair competition, for example, if there had been a common international understanding on what constituted ethical corporate conduct in this commercial area (Knieper and Fromm, 1980: 2020; Oppenhoff, 1980: 862; Hohloch, 1981: 691; Hollmann, 1981: 10; Katzenberger, 1981: 9; Sack, 1998: 510). ${ }^{20}$ The common understanding could have been expressed in an international Convention signed by a considerable number of States. ${ }^{21}$

The new Act against Unfair Competition (UWG) no longer uses the standard of 'good commercial morals', instead referring to 'fairness in competition'. However, the new section 3 UWG still accepts the relevance of commercial customs and generally acknowledged rules (Köhler, 2004: 383).

18 BGH, 27.6.1958 in BGHZ 28 at 54 (direct marketing by wholesalers to consumers constitutes unfair competition only in exceptional cases, ie, if the wholesaler takes advantages of his cost prices to undercut retail sellers). For infringements of rules laid down in collective bargaining in detail: BGH, 3.12.1992 in NJW 1993 at 1010-12.

19 BGH, 9.5.1980 in NJW 1980 at 2018-20: Asbestimporte.

20 Competition 'contra bonos mores', BGH, 9.5.1980 in NJW 1980 at 2018-Asbestimporte; the Convention had not even been ratified by the country of production, South Korea.

${ }^{21}$ BGH, 9.5.1980 in NJW 1980 at 2018-20-Asbestimporte. 
As a result, the German Federal Civil Court's ruling in the Asbestos case still serves as a relevant reference point, since it focused on 'commercial' morals in trade. Consequently, internationally acknowledged norms and standards that mirror fundamental ideas of fair competition constitute important criteria for the assessment of the fairness of transnational commercial practices to the extent that these standards have achieved wide acceptance and are applicable to the distribution of goods, not exclusively to production (Däubler, 1995: 486).

\section{B. Transnational Social Standards and the Relevance of Codes of Conduct}

One of the reasons why the Asbestos case has rarely been applied in other rulings is due to the uncertainty of what internationally acknowledged minimum social standards are exactly (Leary, 1996: 202). What about the infringement of international minimum standards such as working hours, minimum working age, health and safety in the workplace, and the right to organise: In cases where they are violated in order to gain a competitive advantage, does such behaviour constitute unfair trading under German law?

Without legitimate or even democratic consent-finding procedures in the transnational sphere, it remains difficult to prove if, and if so, what kind of, universal consents on specific social values actually exist. With the 1998 Declaration on core labour standards, the ILO is continuously trying to focus its work on promoting the effective implementation of its Conventions through transnational corporations. Therefore, the ILO declared the standards set out under the ILO Conventions on the abolition of forced labour and child labour, on non-discrimination, on freedom of association, and on collective bargaining ${ }^{22}$ to be core labour standards that are to be respected by every ILO Member State, regardless of ratification. Additionally, the ILO now also turns directly to enterprises and their associations for implementation.

In the wake of the 1998 ILO Declaration on core labour standards, considerable standardisation in standard-setting has taken place. Certification agencies and the labelling of products, processes, or firms have played important roles in this regard by professionalising the marketing of social standards. This includes, for example, the SA (Social Accountability) 8000certificate (Köpke and Röhr, 2003: 78), ${ }^{23}$ and in the textile and sports industry, the FLA label (Köhnen, 2002: 15; Köpke and Röhr, 2003: 76) ${ }^{24}$. Since their reform in 2000, the influential OECD-Guidelines for Multinational

22 See nn 4-6 above.

${ }^{23}$ Cp 'Social Accountability International', (http://www.sa8000.org/SA8000/SA8000.htm).

${ }^{24}$ Cp Fair Labor Association, 'Workplace Code of Conduct' (http://www.fairlabor.org/all/ code/index.html). 
Enterprises also refer to the ILO core labour norms in the section on 'social standards'. The same is true for the Global Compact. One interviewee referred to these guidances as 'what is commonly accepted'. ${ }^{25}$ Undertakings and agreements are, in part, also guided by model codes. Every global union federation has created a model code, which in turn draws on the model code of the International Federation of Free Unions. Some enterprise associations, such as the World Association of the Sports Goods Industry (WFSGI), also have model codes of conduct that are informed by the ILO core labour standards.

Another aspect of the legal relevance of codes of conduct is that they contribute to the emergence of transnational law. It is well accepted that international guidelines or private codes of conduct can express collective ideas of fairness and justice of the quality needed for their transformation into hard law. Their transformational value especially depends on the degree of consent on the part of relevant actors in the respective sector (Baade, 1979: 26; Meessen, 1981: 1131; Hailbronner, 1982: 116). Even when lacking a regulatory character, codes of conduct still serve to convert existing international law standards into standards 'commonly accepted' in transnational production and distribution.

\section{CONCLUSIONS}

Through the adoption of codes of conduct on transnational social standards, corporations aim to participate in the enforcement and adaptation of rules developed elsewhere. Even if the enforcement mechanisms included in such declarations exhibit weighty defects, the corporate undertakings still actively contribute to the emergence of transnational labour standards.

Private regulatory processes, which extend beyond the reach of nation states, have been described and analysed regarding their role in the emergence of 'transnational law' (Albert and Lehmkuhl, 2002: 159; Calliess, 2002: 188). Until now, the debate around the quality and importance of transnational law has focused on the lex mercatoria (Berger, 1996: 32; Berger et al, 2002: 12; Dasser, 2001: 189). However, the regulation of working conditions through corporate codes of conduct and framework agreements also exhibits the private character and the horizontal (as opposed to hierarchical) coordination of behaviour that are seen as characteristic for transnational law (Gessner, 2002: 280). These instruments of transnational law are important steps on the way from private standards to commercial rules and from commercial rules to law-that is, on the way from 'soft law' to 'hard law' (Berger, 1996: 192; Berger et al, 2002: 12).

${ }^{25}$ See also text at $\mathrm{n} 7$ above for the 'global eight'. 
In the case of social standards, through the ILO core labour norms, international law plays a leading role in the creation of transnational law. By entering into the field of social standards, private codes of conduct thus also contribute to making international labour standards legally binding in national 'reflective' hard law-which (like hard law rules on unfair competition) refers to transnational soft law.

\section{REFERENCES}

Albert, M and Lehmkuhl, D (2002) 'Transnationales Recht' 23 Zeitschrift für Rechtssoziologie 159.

Alston, P (2004) 'Core Labour Standards and the Transformation of the International Labour Rights Regime' European Journal of International Law 15.

Baade, HW (1979) 'The Legal Effects of Codes of Conduct for Multinational Enterprises' German Yearbook of International Law 26.

Ballreich, H (1989) 'Nachdenkliches über "Soft law"' Gewerblicher Rechtsschutz und Urheberrecht Internationaler Teil 383.

Bassen, A, Jastram, S, and Meyer, K (2005) 'Corporate Social Responsibility. Eine Begriffserläuterung' 6 Zeitschrift für Wirtschafts- und Unternehmensethik 231.

Berger, KP (1996) Formalisierte oder 'schleichende' Kodifizierung des transnationalen Wirtschaftsrechts (Berlin/New York, de Gruyter).

Berger, KP, Dubberstein, H, Lehmann, S, and Petzold, V (2002) 'Anwendung Transnationalen Rechts in der internationalen Vertrags- und Schiedspraxis' 101 Zeitschrift für vergleichende Rechtswissenschaft 12.

Blanke, T and Hoffmann, J (2006) 'Auf dem Weg zu einem Europäischen Sozialmodell. Voraussetzungen, Schwierigkeiten und Perspektiven einer europäischen Sozialpolitik' Kritische Justiz 134.

Calliess, G-P (2000) 'Das Tetralemma des Rechts' 21 Zeitschrift für Rechtssoziologie 293.

— (2002) 'Reflexive Transnational Law' 23 Zeitschrift für Rechtssoziologie 188.

Colucci, M (2000) 'Implementation and monitoring of codes of conduct. How to make codes of conduct effective?' 37 Bulletin of Comparative Labour Relations 277.

Dasser, F (2001) 'Lex Mercatoria' in RP Appelbaum, WLF Festiner, and V Gessner (eds), Rules and Networks: The legal culture of global business transactions (Oxford; Portland, Oregon, Hart).

Däubler, W (1995) 'Sozialstandards im internationalen Wirtschaftsrecht' in F v Westphalen (ed) Lebendiges Recht. Festschrift für Reinhold Trinkner zum 65. Geburtstag (Heidelberg, Verlag Recht und Wirtschaft).

Dilling, O (2005) 'Die Produktionsbedingung als Produkteigenschaft' in G Winter (ed), Die Umweltverantwortung multinationaler Unternehmen (Baden-Baden, Nomos).

Dubin, L (1999) 'The Direct Application of Human Rights Standards to, and by, Transnational Corporations' 61 Review of the International Commission of Jurists.

Ehricke, U (1989) 'Soft law_Aspekte einer neuen Rechtsquelle' Neue Juristische Wochenschrift 1907.

Engels, C (2000) 'Codes of Conduct. Freedom of association and the right to bargain collectively' 37 Bulletin of Comparative Labour Relations 219. 
Ewert, J (1997) Wettbewerbsrechtliche Beurteilung von Umweltwerbung obne Produktqualitätsbezug nach deutschem Recht und europäischem Gemeinschaftsrecht (Berlin, Duncker \& Humblot).

Fichter, M and Sydow, J (2002) 'Using Networks Towards Global Labor Standards? Organizing Social Responsibility in Global Production Chains' Industrielle Beziehungen 357.

Gessner, V (2002) 'Rechtspluralismus und globale soziale Bewegungen' 23 Zeitschrift für Rechtssoziologie 280.

Glinski, C (2005) 'Produktionsaussagen und Vertrauensschutz im Kauf- und Werberecht' in G Winter (ed), Die Umweltverantwortung multinationaler Unternehmen (Baden-Baden, Nomos).

Greven, T (2006) 'Auf dem Prüfstand: Gewerkschaftsstrategien zur Regulierung globaler Konkurrenz’ WSI-Mitteilungen 10.

Habermas, J (1997) Faktizität und Geltung, 5th edn (Frankfurt am Main, Suhrkamp).

Hailbronner, K (1982) 'Rechtswirkungen des EG-Südafrikakodex' Recht der Internationalen Wirtschaft 113.

Hammer, N (2005) 'International Framework Agreements: global industrial relations between rights and bargaining' Transfer. European review of labour and research.

Hauser-Ditz, A and Wilke, P (2005) Corporate Social Responsibility-Soziale und ökologische Verantwortung von Unternehmen. Eine Betriebsrätebefragung $z u$ den Handlungsfeldern für Arbeitnehmervertretungen (Düsseldorf, HBSArbeitspapier).

Hepple, B (2005) Labour Laws and Global Trade (Oxford/Portland, Oregon, Hart). Herberg, M (2002) 'Codes of Conduct und kommunikative Vernunft' 22 Zeitschrift für Rechtssoziologie 45.

- (2005) 'Erzeugen multinationale Unternehmen ihr eigenes Umweltrecht?' in $\mathrm{G}$ Winter (ed), Die Umweltverantwortung multinationaler Unternehmen (BadenBaden, Nomos).

Hoffmann, J (2004) 'Co-ordinated Continental European Market Economies under Pressure from Globalisation: Germany's Rhineland capitalism' 5 German Law Journal No 8 (1 August 2004).

Hohloch, G (1981) 'Zum Urteil des BGH vom 9.5.1980 (Asbestimporte)' Juristische Schulung 691.

Hollmann, HH (1981) 'Anmerkung zur Entscheidung des BGH vom 9.5.1980 (Asbestimporte)' Juristische Arbeitblätter 120.

Kaelble, H (2000) 'Wie kam es zum Europäischen Sozialmodell?' in A Aust, S Leitner, and S Lessenich (eds), Sozialmodell Europa (Opladen, Leske+Budrich).

Katzenberger, P (1981) 'Inländischer Wettbewerb, ordre public und ausländisches Arbeitsschutzrecht' Praxis des Internationalen Privat- und Verfahrensrecht 9.

Knieper, R and Fromm, H (1980) 'Anmerkung zur Entscheidung des BGH vom 9.5.1980 (Asbestimporte)' Neue Juristische Wochenschrift 2020.

Kocher, E (2002) 'Private Standards between Soft Law and Hard Law-The German Case' The International Journal of Comparative Labour Law and Industrial Relations 265.

_ (2004a) 'Selbstverpflichtungen von Unternehmen zur sozialen Verantwortung' Recht der Arbeit 27. 
— (2004b) 'Mindeststandards vor Gericht' in T Brühl, H Feldt, B Hamm, H Hummel and J Martens (eds), Unternehmen in der Weltpolitik (Bonn, Verlag JHW Dietz).

_ (2005) 'Unternehmerische Selbstverpflichtungen im Wettbewerb' Gewerblicher Rechtsschutz und Urheberrecht 647.

Köhler, H (2004) 'Der Rechtsbruchtatbestand im neuen UWG' Gewerblicher Rechtsschutz und Urheberrecht 383.

Köhnen, H (2002) 'Haben Menschenrechtsverletzungen ein System?' in Wal-Mart's Verhaltenskodex und die Realität bei Zulieferern in ausgewählten Ländern (Düsseldorf, Hans-Böckler-Stiftung).

Köpke, R and Röhr, W (2003) Codes of Conduct (Köln, PapyRossa Verlag).

Körting, C (2006) 'Global Compact-Bilanz und Perspektiven' in J Martens, W Oesterheld, and P Eisenblätter (eds), Verbindliche Regeln für MultisCorporate Accountability-Zwischenbilanz und Zukunftsperspektiven (http:// www.globalpolicy.org/eu/de/publ/corporate-accountability-dokumentation.pdf).

KPMG (Kolk, van der Veen, Pinkse, Fortanier, Peters and Extercatte) (2005), International Survey of Corporate Responsibility Reporting (Amsterdam: KPMG) (http://ec.europa.eu/employment_social/soc-dial/csr/060403/kpmgsurvey2005_ en.pdf).

Langille, BA (2005) 'Core Labour Rights-The True Story' 16 European Journal of International Law 409.

Lavranu, A (2000) 'Europa-Wertegemeinschaft oder Interessenkongruenz?' in A Aust, S Leitner, and S Lessenich (eds), Sozialmodell Europa (Opladen, Leske+Budrich).

Leary, VA (1996) 'Workers' Rights and International Trade: The Social Clause (GATT, ILO, NAFTA, US Laws)' in J Bhagwati and RE Hudec, Fair Trade and Harmonization, vol 2 (Cambridge, MA, MIT Press).

Meessen, KM (1981) 'Internationale Verhaltenskodizes und Sittenwidrigkeitsklauseln' Neue Juristische Wochenschrift 1131.

Ölz, M (2002) 'Die Kernarbeitsnormen der Internationalen Arbeitsorganisation im Licht der neuen handelspolitischen “Sozialklausel” der Europäischen Union' Zeitschrift für internationales und ausländisches Arbeits- und Sozialrecht 330.

Oppenhoff, W (1980) 'Anmerkung zur Entscheidung des BGH vom 9.5.1980' Gewerblicher Rechtsschutz und Urheberrecht 862.

Pfarr, H and Kocher, E (1998) Kollektivverfahren im Arbeitsrecht (Baden-Baden, Nomos).

Riedel, S, Deuerlein, I, and Pomper, F (2003) Die gesellschaftliche Verantwortung österreichischer Unternehmen. Ergebnisse einer empirischen Untersuchung (Wien, CSR Austria).

Riess, B and Peters, A (2005) Die gesellschaftliche Verantwortung von Unternehmen (Güterloh, Bertelsmann-Stiftung) (http://www.buergerstiftungen.de/cps/rde/xbcr/ SID-0A000F0A-77FA41BB/buergerstiftungen/Unternehmensbefragung_CSR.pdf).

Rott, P and Glinski, C (2003) 'Umweltfreundliches und ethisches Konsumverhalten im harmonisierten Kaufrecht' Europäische Zeitschrift für Wirtschaftsrecht 649.

Sack, R (1998) 'Die wettbewerbsrechtliche Durchsetzung arbeitsrechtlicher Normen' in P Hanau (ed), Festschrift für Günter Wiese zum 70. Geburtstag (Neuwied, Luchterhand).

Scherrer, C, Greven, T, and Frank, V (1998) Sozialklauseln, Arbeiterrechte im Welthandel (Münster: Westfälisches Dampfboot). 
Sheikh, S (2002) 'Promoting Corporate Social Responsibility Within the European Union' 13 International Company and Commercial Law Review 143.

Simma, B and Zöckler, M (1996) 'Law-making by Universal Organizations' in B Maydell and A Nußberger (ed), Social Protection by Way of International Law (Berlin, Duncker \& Humblot).

Su-Ping, L (1999/2000) 'Corporate Codes of Conduct and the FTC: Advancing Human Rights through Deceptive Advertising Law' 38 Columbia Journal of Transnational Law 601.

Tapiola, K (2000) 'The ILO Declaration on Fundamental Principles and Rights at Work and its Follow-up' 37 Bulletin of Comparative Labour Relations 9.

Teubner, G (1971) Standards und Direktiven in Generalklauseln (Frankfurt am Main, Athenäum-Verlag).

— (1984) 'Verrechtlichung' in F Kübler (ed), Verrechtlichung von Wirtschaft, Arbeit und sozialer Solidarität (Baden-Baden, Nomos).

Teubner, G and Willke, H (1984) 'Kontext und Autonomie: Gesellschaftliche Selbststeuerung durch reflexives Recht' 5 Zeitschrift für Rechtssoziologie 4.

van Liemt, G (2000) 'Codes of Conduct and International Subcontracting: A 'private' road towards ensuring minimum labour standards in export industries' 37 Bulletin of Comparative Labour Relations 177.

Weinz, W (2006) 'Globale Rahmenvereinbarungen zwischen Gewerkschaften und Konzernen' in J Martens (ed), Corporate Accountability-Zwischenbilanz und Zukunftsperspektiven (http://www.globalpolicy.org/eu/de/publ/corporateaccountability-dokumentation.pdf).

Wilhelm, A and Mauritz, C (2005) Die Nachhaltigkeitsleistungen deutscher Großunternehmen (http://www.scoris.de/download/scoris_dax30_studie_2005.pdf).

Winter, G (2005) 'Die Umweltverantwortung multinationaler Unternehmen' in $\mathrm{G}$ Winter (ed), Die Umweltverantwortung multinationaler Unternehmen (BadenBaden, Nomos). 